\title{
To Study The Behavior Of Interlocking Of Masonry Units/Blocks
}

\author{
Sajad Ahmad ${ }^{1}$, Sadam Hussain ${ }^{2}$, Mohd Awais ${ }^{3}$, Mohd Asif ${ }^{4}$, \\ Hakim Muzamil ${ }^{5}$, Rafiq Ahmad ${ }^{6}$, Shakeel Ahmad ${ }^{7}$ \\ (Assistant professor IUST Kashmir; $)^{l}$ \\ (B.Tech Civil Engineering; $)^{2},(\text { B.Tech Civil Engineering; })^{3}{ }^{3}$ (B.Tech Civil Engineering; $)^{4}$, \\ (M.Tech Civil Engineering; $)^{5}$, (Assistant professor IUST Kashmir;) ${ }^{6}$ (Engineering Geologist JKSPDC \\ Srinagar; $)^{7}$
}

\begin{abstract}
The word "masonry" is a general term that applies to construction using hand-placed units of clay, concrete structural clay tile, glass block, natural stones and the like. The term masonry also refer to the units themselves. The common materials of masonry units are brick, stone, marble, granite, travertine, limestone, cast stone, concrete block, glass block, stucco, and tile. Masonry unit are bound generally with a highly durable form of construction. However, the materials used, the quality of the mortar and workmanship, and the pattern in which the units are assembled can significantly affect the durability of the overall masonry construction. .Mainly the weakest part of a masonry wall is the mortar joint, as the substitution of lime for aggregate reduces the overall strength of the joint. The need to butter and precisely fit each block necessitates the use of skilled, and typically highly paid, masons. Also, the mortar used to butter the units often hardens on the inside of openings within the blocks, preventing or hindering the insertion of insulation and/or reinforcements within the openings. One solution to the lack of strength of mortar joints has been to dry stack the masonry units. However, dry stacking of walls is not without drawbacks. First, like the staking of mortar walls, care must be taken to ensure that the units are properly aligned with one another. This can be a painstaking process that greatly increases the time required to build such a wall. Second, the lack of motor in the joints between units allows air to easily pass through the joints and requires that a skin or other air barrier be used in connection with the walls. Third, the lack of mortar to hold the units in horizontal alignment make the use of many additional reinforcements, such as steel rebar, stabilizers, or the like, absolutely necessary in these types of walls. Therefore, there is a need for a masonry unit and masonry system that allow structures to be dry stacked without mortar, that allows masonry units to be quickly and accurately aligned during stacking, that does not require the use of separate stabilizers or other means for preventing deflection of the structure formed thereby, that produces substantially straight and stable walls, that retards the flow of air from one face of the wall to the other, that may be manufactured of a mixture of concrete and lightweight aggregate, and that will readily accept plaster or mesh substrates upon its outside surfaces without the need for sanding or special treatment. One such unit is the Interlocking Masonry Unit/Block'. This work examines the Compressive Strength Property of 'Interlocking Masonry Units/Blocks' and compares it with strength behavior of other masonry units. The increase in strength w.r.t. the concrete masonry hollow is by $20 \%$ and w.r.t. the brick is by $40 \%$. Besides, the increase in compressive strength is also witnessed when compared with the interlocking features. Interlocking mortar increases strength by $30 \%$ w.r.t. the prism without interlocking mortar. Further cost saving is achieved because the simplicity with which the blocks can be laid and aligned reduces the number of high wage skilled masons required on a construction project. When compared to convention masonry block construction, interlocking blocks, which are dry assembled, save a great deal of mortar Because of the ease and economy with which interlocking block walls can be built, load bearing walls can be used where infill walls would normally be placed, thereby providing both additional strength and load bearing ability to accept future additions to the building. Interlocking block construction techniques can be used for everything from single to multi-story construction.
\end{abstract}

Keywords: - Compressive Strength, Crushing Value, Interlocking Masonry Units/Blocks, Stress-Strain Relation

\section{INTRODUCTION}

Masonry is commonly used for the walls of buildings, retaining walls and buildings. Brick and concrete block are the most common types of masonry in use in industrialized nations and may be either weight-bearing or a veneer. Concrete blocks, especially those with hollow cores, offer various possibilities in masonry construction. They generally provide great compressive strength, and are best suited to structures with light transverse loading when the cores remain unfilled. Filling some or all of the cores with concrete or concrete with steel reinforcement (typically rebar) offers much greater tensile and lateral strength to structures. 
Masonry is non-combustible product. Masonry walls are more resistant to projectiles, such as debris from hurricanes or tornadoes. Masonry structures built in compression preferably with lime mortar can have a useful life of more than 500 years as compared to 30 to 100 for structures of steel or reinforced concrete.

Interlocking blocks offer numerous advantages to other building materials. The materials required for production are widely available so they do not have to be shipped in from long distances. Since the manufacturing process is a simple one, production facilities can be easily set up at convenient geographical locations, once again reducing the cost of transporting them to the construction site. In the case of very large construction projects, an interlocking block production facility can be set up at the construction site to provide the most cost effective supply solution.

Another cost saving is achieved because the simplicity with which the blocks can be laid and aligned reduces the number of high wage skilled masons required on a construction project. When compared to convention masonry block construction, interlocking blocks, which are dry assembled, save a great deal of mortar which is normally used for vertical and horizontal joints, which again produces savings in terms of both cost and time.

Any time you can save time is critically important. This means you can start building later on in the summer knowing you can have it completed before the rain and snow begin to arrive in sleets which can severely hamper the progress on any work site. This enables an owner or a business to be able to begin selling goods and/or services throughout the winter and sooner than if a building could not be started at all until the spring.

The structural stability and durability of interlocking blocks is much greater than that which is offered by timber construction. Another benefit is that, unlike timber, interlocking blocks are immune to termite and other insect damage. Vulnerable and high stress parts of a building can be reinforced by running steel bars through the aligned holes of the blocks. Because of the ease and economy with which interlocking block walls can be built, load bearing walls can be used where infill walls would normally be placed, thereby providing both additional strength and load bearing ability to accept future additions to the building. Interlocking block construction techniques can be used for everything from single to multi-story construction.

\subsection{Cement and Aggregates}

\section{MATERIALS USED}

Khyber ordinary Portland cement of 43 grade confining to IS 8112 was used throughout the work. Fine aggregates used throughout the work comprised of clean river sand with maximum size of $4.75 \mathrm{~mm}$ conforming to zone II as per IS383-1970 with specific gravity of 2.6. Coarse aggregates used consisted of machine crushed stone angular in shape passing through $20 \mathrm{~mm}$ IS sieve and retained on $4.75 \mathrm{~mm}$ IS sieve with specific gravity of 2.7 .

\subsection{Water}

Water used for mixing and curing is clean reasonably clear and free from objectionable quantities of shell, silts, alkalis, acids etc. Water tested shall be in accordance with IS 3025, Maximum permissible limits of deleterious materials in water shall be as given in IS 456.

\subsection{Concrete}

The concrete mix used for the manufacturing of interlocking blocks/units was M25 as per IS 10262.Concrete blocks made where solid and as per referred to by its nominal dimension. Blocks were considered as per IS 2185 (Part I).

\subsection{Mortar}

Mortar was prepared by using anti-shrinkage compound. Mixing of mortar was done by mechanical mixers only. Non shrinking compound were added to the mortar as per direction of manufacturer of the chemical. Volumetric mixing was used based on dry volumes of each ingredient. Sand was added suitably to allow for bulkage. Bulkage was determined as specified in IS 2386 (Part III). After addition of water the mixer was ran for a minimum of 3 minutes. The mortar mixed was consumed within 30 minutes of its mixing. ।

\section{MODEL FEATURES OF INTERLOCKING BLOCKS}




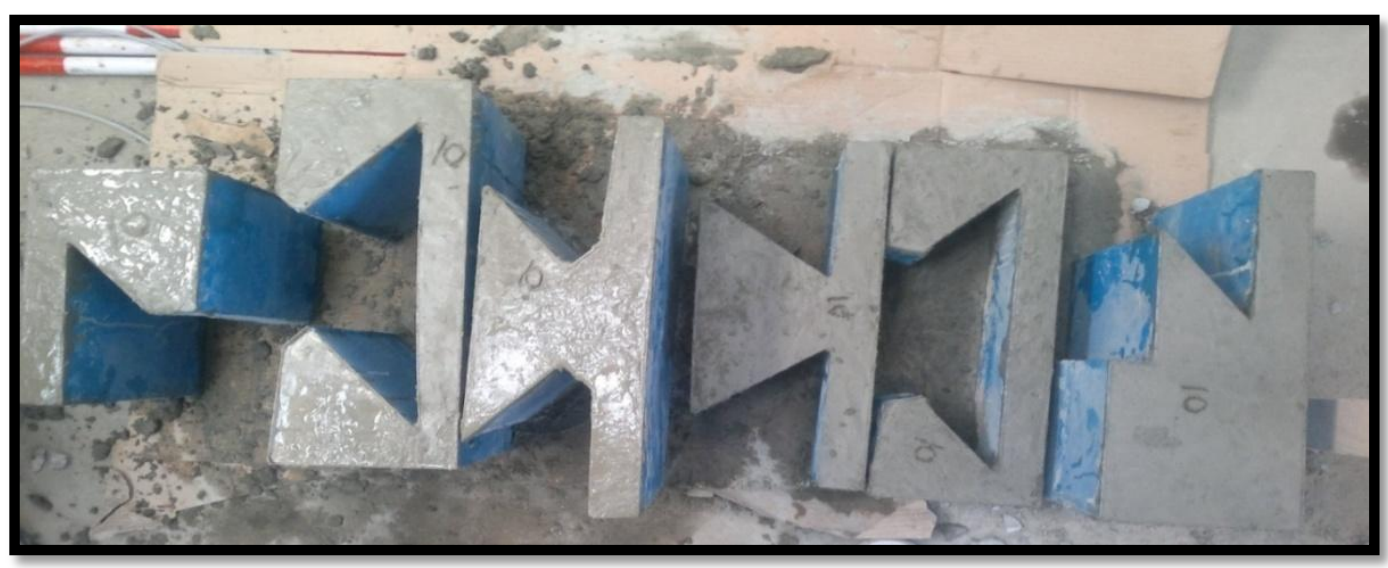

Figure 1. Interlocking Arrangement (male and female samples)

The main features of interlocking blocks are as under :

1). The interlocking blocks/units have very high compressive strength as compared to ordinary bricks.

2). The load bearing capacity of these units/blocks is very high as compared to normal bricks.

3). Effective cost of one block of interlocking unit is much less than the bricks covering up the same volume.

4). Construction of these units/blocks comprises of easy and feasible process.

5). During interlocking of a single block/unit use of mortar is not necessary as the compressive strength remains same with or without use of mortar.

\subsection{Interlocking Arrangement}

The Interlocking adopted is given as in figures below.
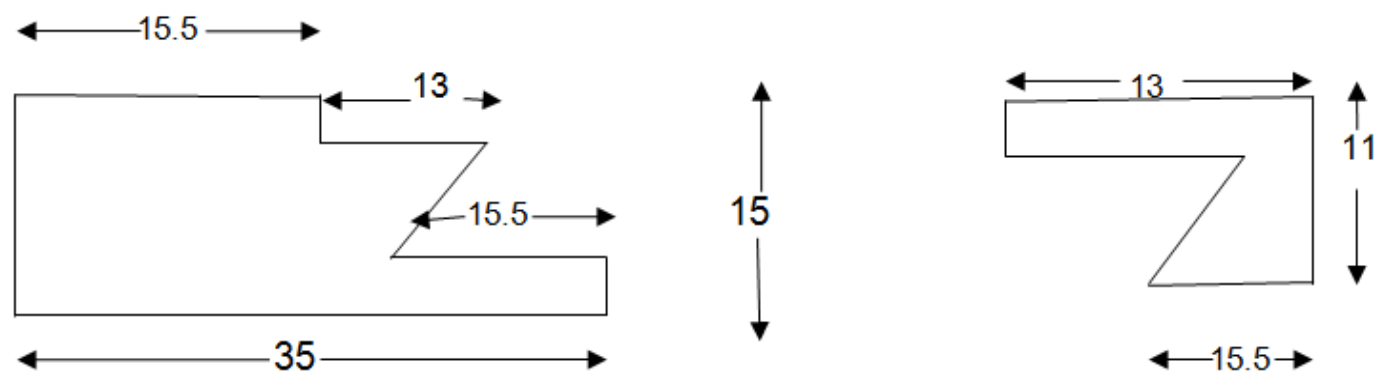

Figure 2a. Sample "a" male and female units/blocks
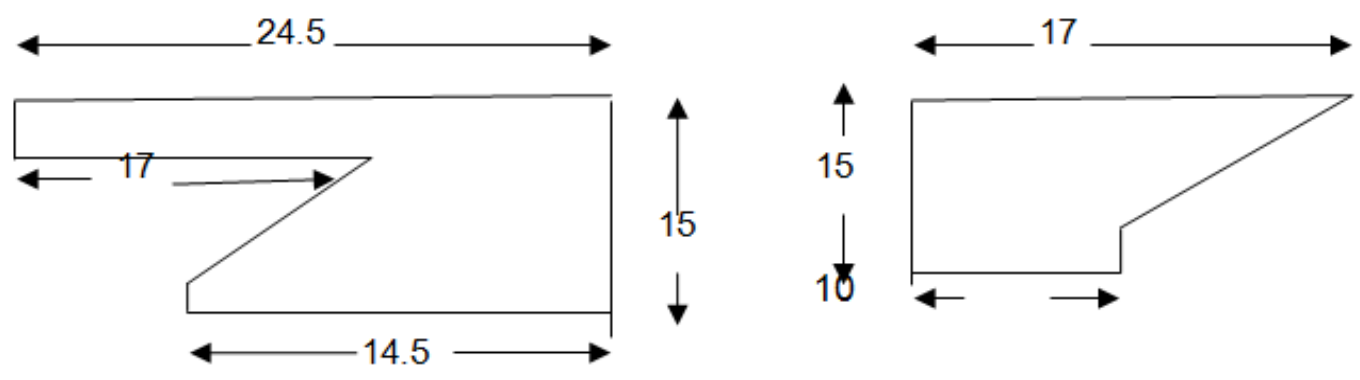

Figure 2b. Sample "b" female and male units/blocks

Figure 2. Interlocking model configuration

\section{IV.}

3.1. Consistency of Cement

\section{EXPERIMENTAL INVESTIGATION}

The Standard Consistency Test was conducted on cement as per IS: 4031 (Part 4) - 1988 using Vicat's Apparatus. The Water-Cement ratio was found equal to 0.45 . 


\subsection{Slump Test}

The Slump Value of Concrete was found as per IS Specifications and was found equal to nearly $35 \mathrm{~mm}$.

3.3. Crushing Value Test

This test was conducted on Interlocking Masonry Units/Blocks using UTM and gave the following results:

Crushing Value:- When load is applied perpendicular to two interlocked bed-blocks (Sample "a"):

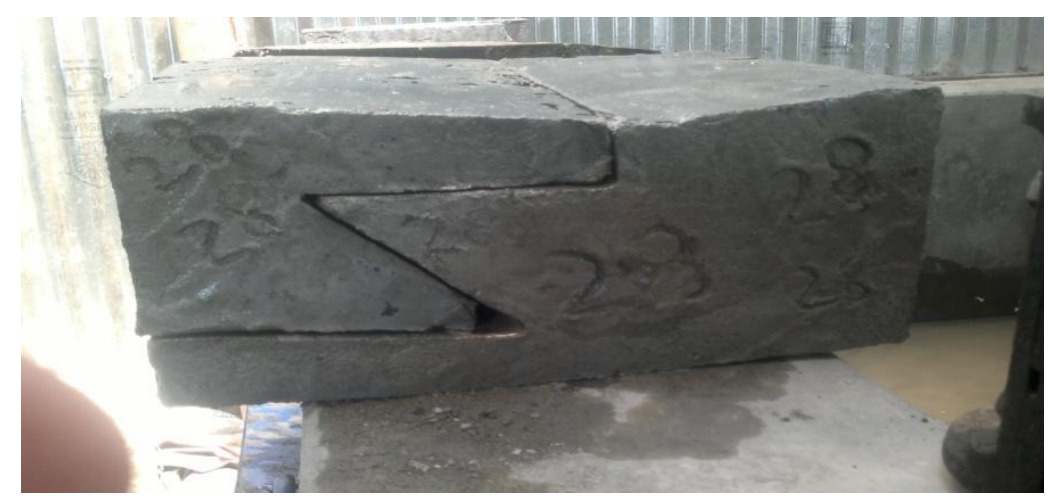

Figure 3: Interlocked Sample 'a' loaded parallel to bed-plane for Crushing strength

For 7 days test:

Peak crushing 7 days load $=359 \mathrm{KN}$ or $359 \times 10^{3} \mathrm{~N}$

Area of block /unit $=(350 \times 310) \mathrm{mm}^{2}=108500 \mathrm{~mm}^{2}$

Therefore, Peak 7 days crushing strength $=$ Peak Load $/$ Total Area

$=359 \times 10^{3} / 108500=3.3087 \mathrm{~N} / \mathrm{mm}^{2}$ say $3.3 \mathrm{~N} / \mathrm{mm}^{2}$

For 28 days test:

Peak crushing 28 days load $=955 \mathrm{KN}$

Now Peak stress is given by Peak load/Total Area

Crushing strength 28 days is $8.8 \mathrm{~N} / \mathrm{mm}^{2}$

Crushing Value:- When load is applied perp. to bed plane of masonry Block/Units-Sample "b":
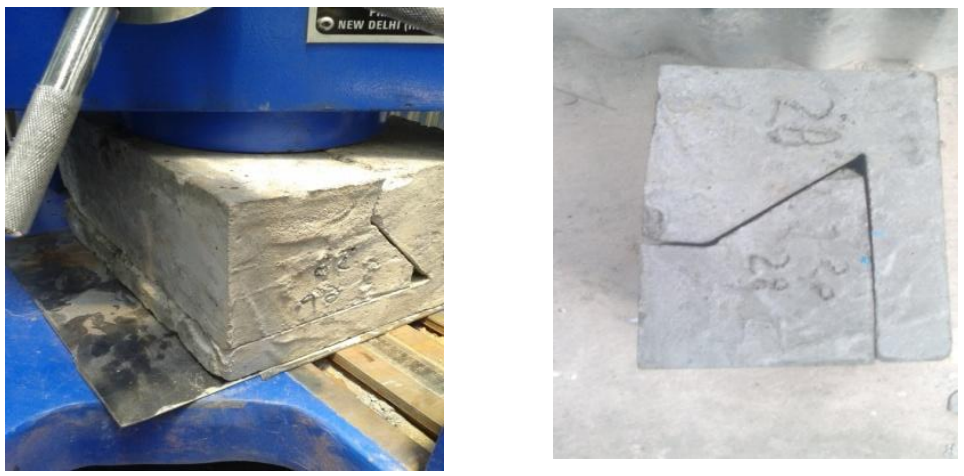

Figure 4: Interlocked Sample 'b' loaded parallel to bed-plane for Crushing strength

For 7 days test:

Peak crushing 7 days Load $=267.55 \mathrm{KN}$

Area of the block/unit $=(290 \times 250) \mathrm{mm}^{2}$

Therefore, Peak crushing strength $=$ Peak Load/Total Area

$$
=267.55 \times 10^{3} / 72500=3.69 \mathrm{~N} / \mathrm{mm}^{2}
$$

After seven days the compressive strength of the block, sample B is $3.69 \mathrm{~N} / \mathrm{mm}^{2}$

For 28 days test:

Peak crushing 28 days load $=900 \mathrm{KN}$

Now Peak stress is given by Peak load/Total Area

Crushing strength 28 days is $12.41 \mathrm{~N} / \mathrm{mm}^{2}$

\subsection{Compressive strength:}

Compressive Strength:- When Prism wall made up by interlocking of masonry units/blocks without using mortar for interlocking of masonry units (Sample ' $a$ '): was tested and following results were found:

Compressive strength 7 days $=$ Load $/$ Area $=350 \times 10^{3} /(300 \times 350)=3.33 \mathrm{~N} / \mathrm{mm}^{2}$

Compressive strength 28 days $=$ Load $/$ Area $=990 \times 10^{3} /(300 \times 350)=9.43 \mathrm{~N} / \mathrm{mm}^{2}$ 

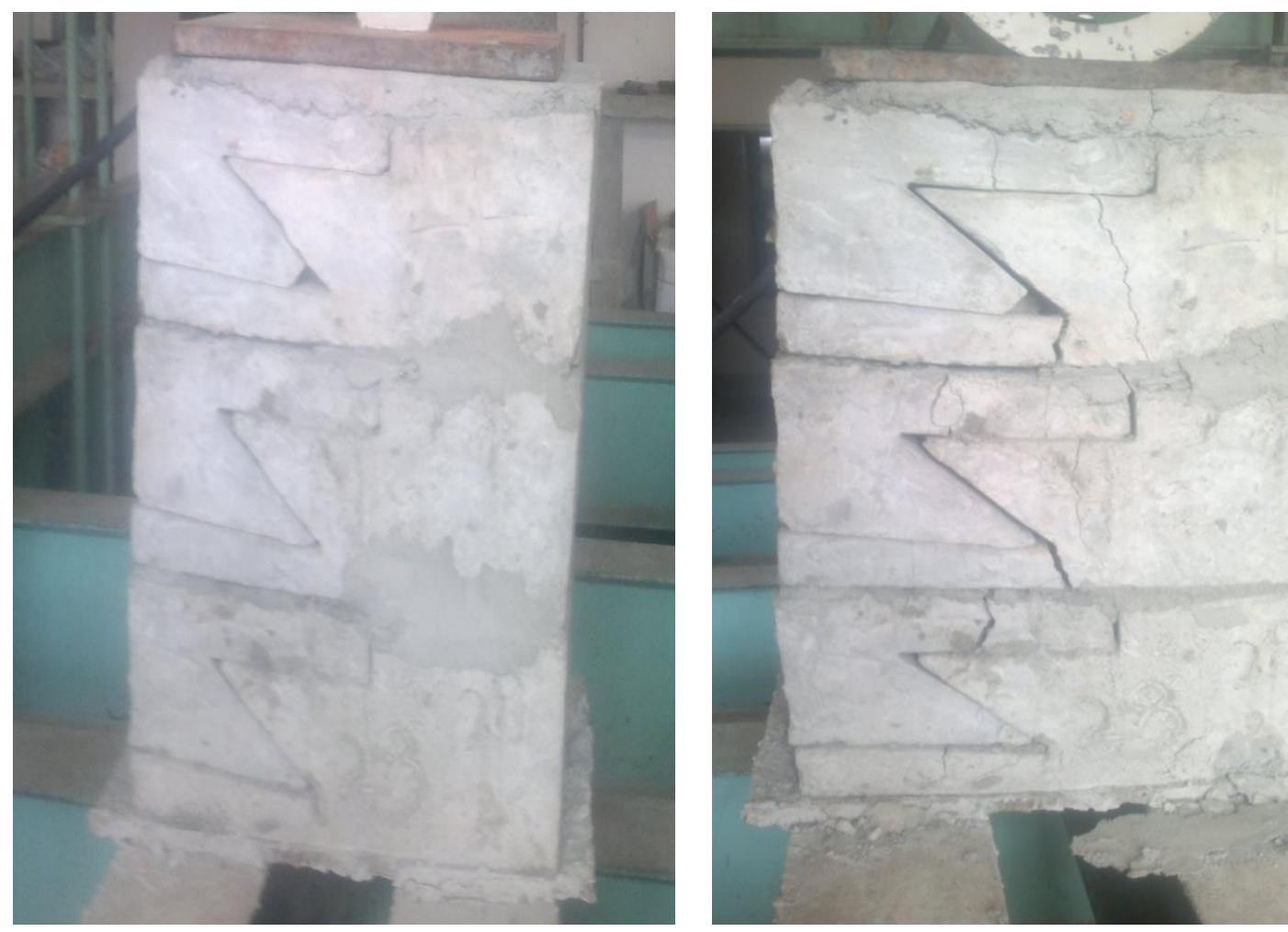

Figure 5: Prism wall without using mortar for interlocking before and after loading Sample 'a'

Compressive Strength:- When load is applied on the prism wall made up of interlocking of masonry units/blocks with using mortar for interlocking of masonry units (Sample 'b'):
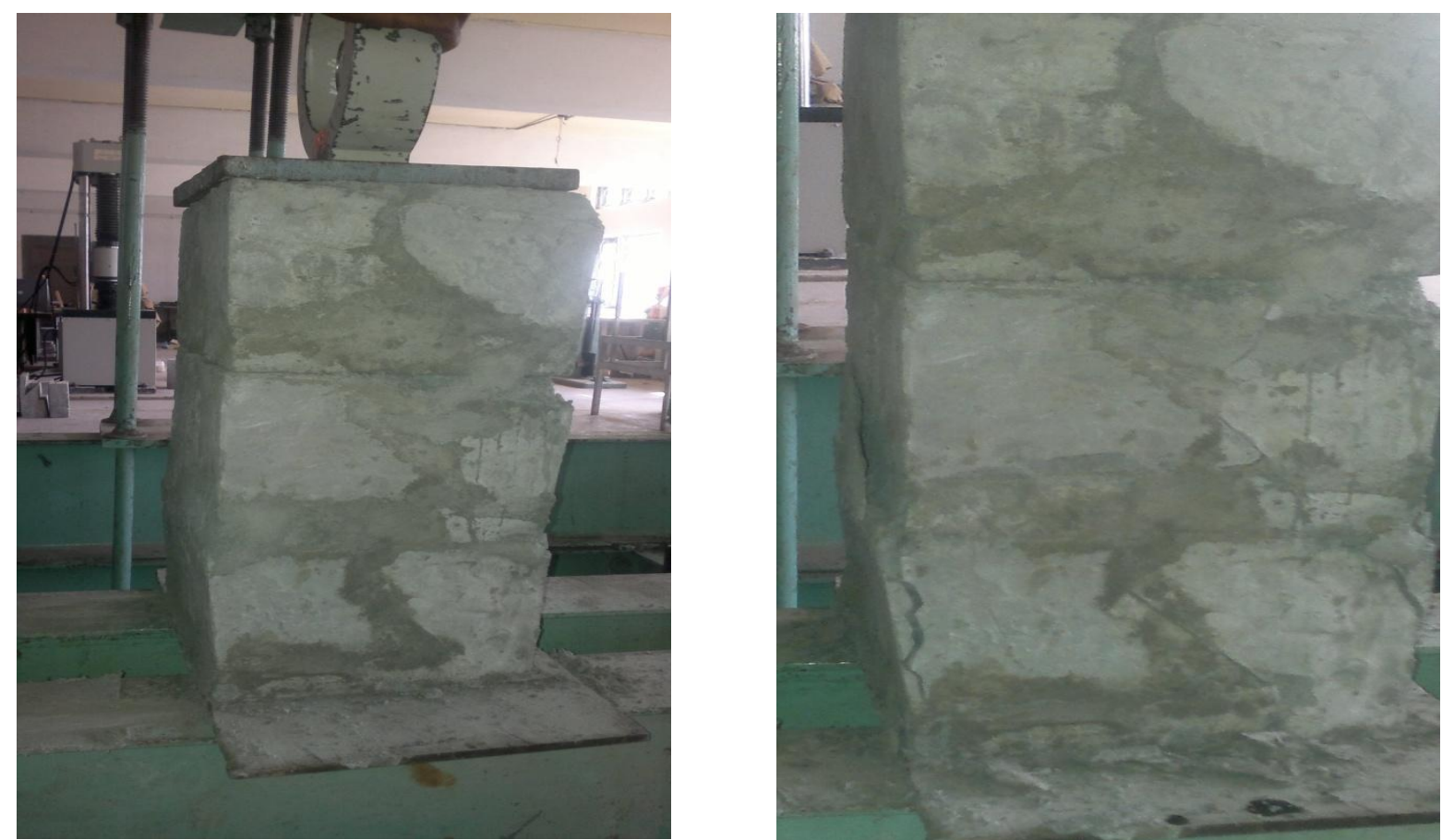

Figure 6: Prism wall with using mortar for interlocking before and after cracking (Sample "b")

\section{RESULTS-DISCUSSION}

\subsection{Comparison:}

1.Sress-Strain Diagram 7 days for Sample 'a' and 'b' Block Prism: 


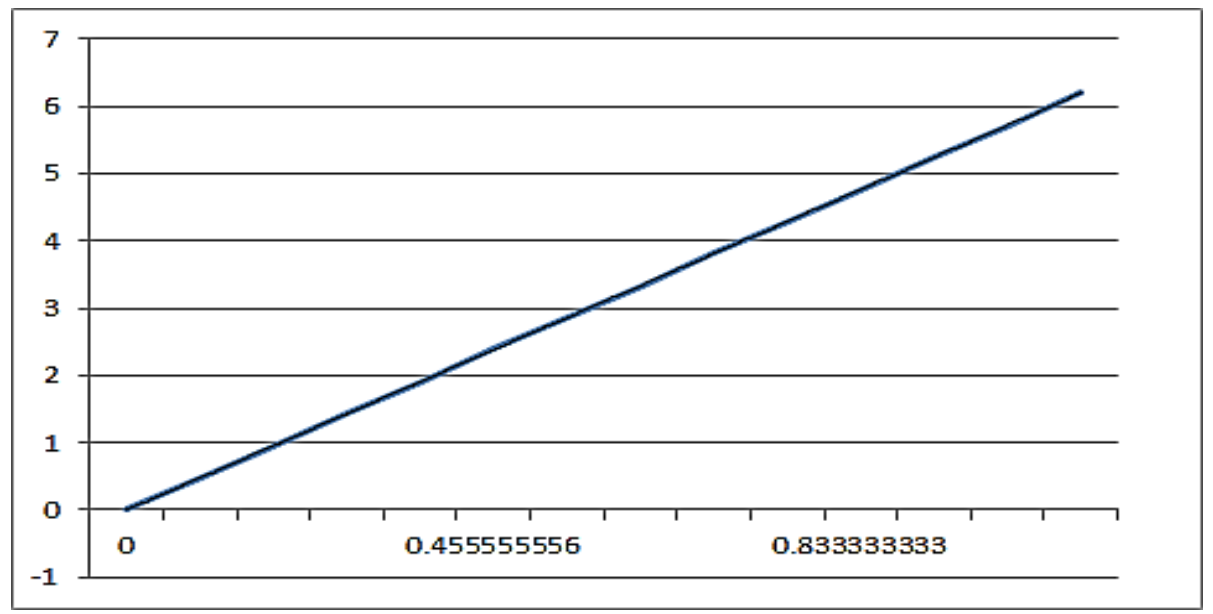

Figure 7:Stress-Strain Diagram 7 days of masonry prism Sample 'a'

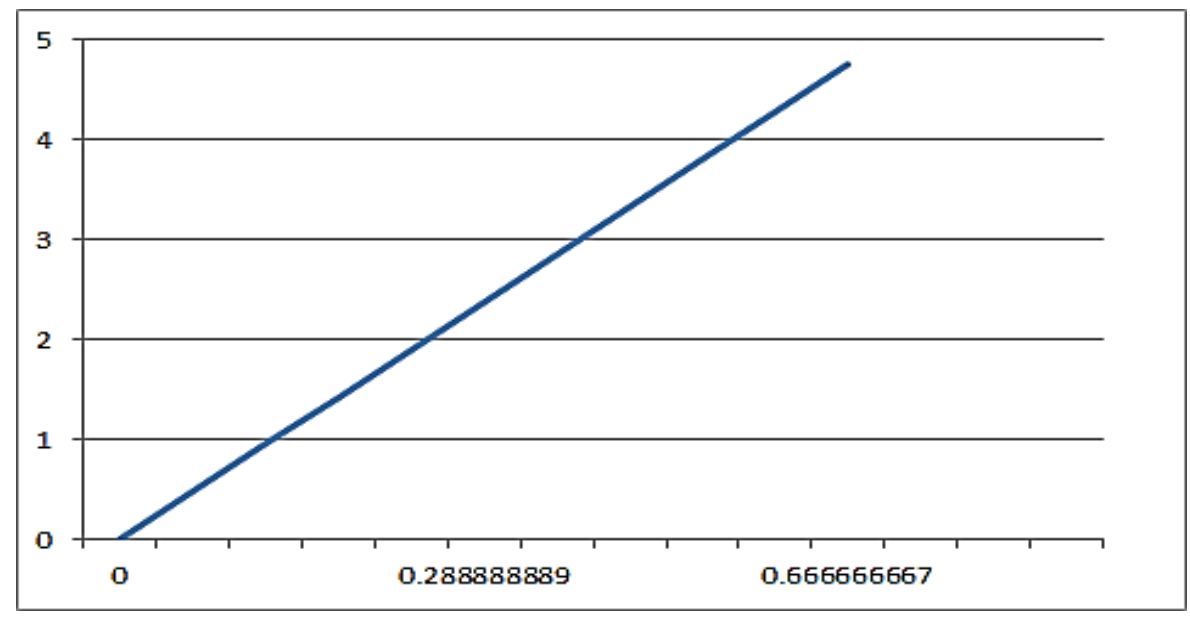

Figure 8: Stress-Strain Diagram 7 days of masonry prism Sample ' $b$ '

2.Sress-Strain Diagram 28 days for Sample 'a' and 'b' Block Prism:

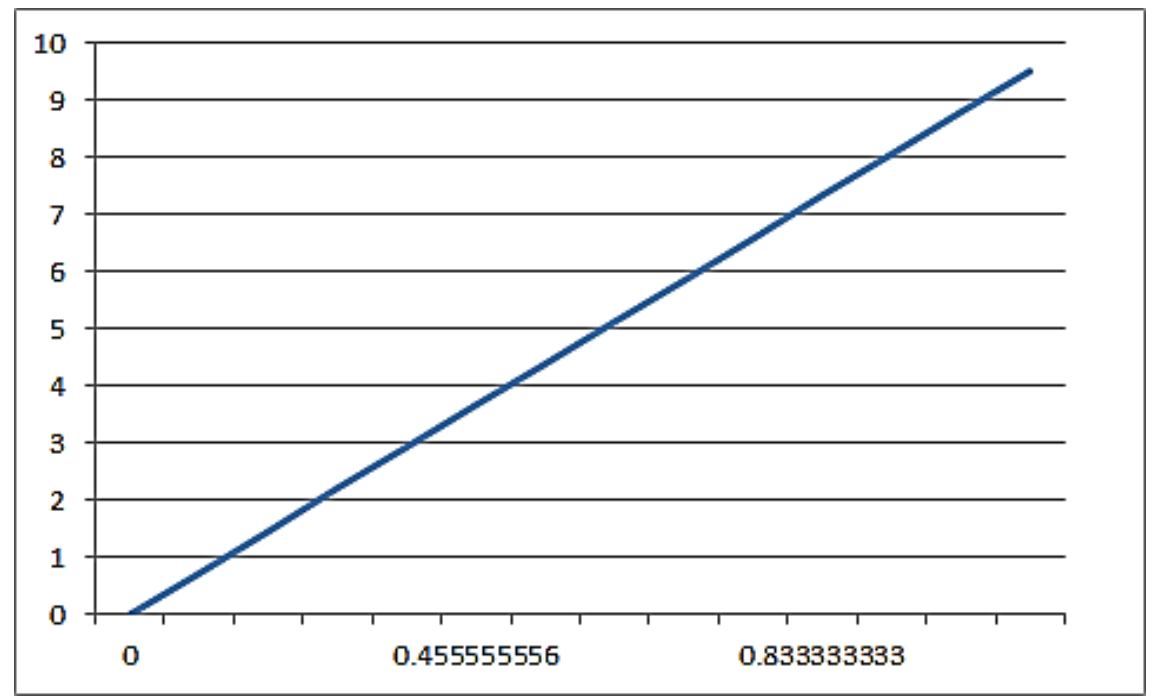

Figure 9: Stress-Strain Diagram 28 days of masonry prism Sample 'a' 


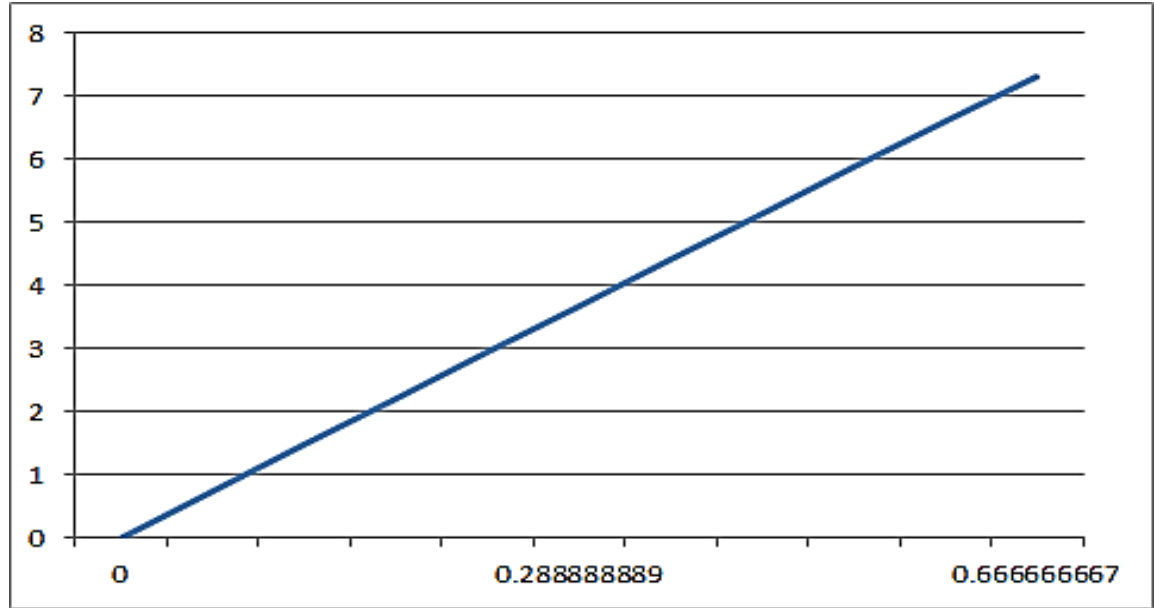

Figure 10: Stress-Strain Diagram 28 days of masonry prism Sample ' $b$ '

3. Sress-Strain Diagram for Brick Masonry 28 days:

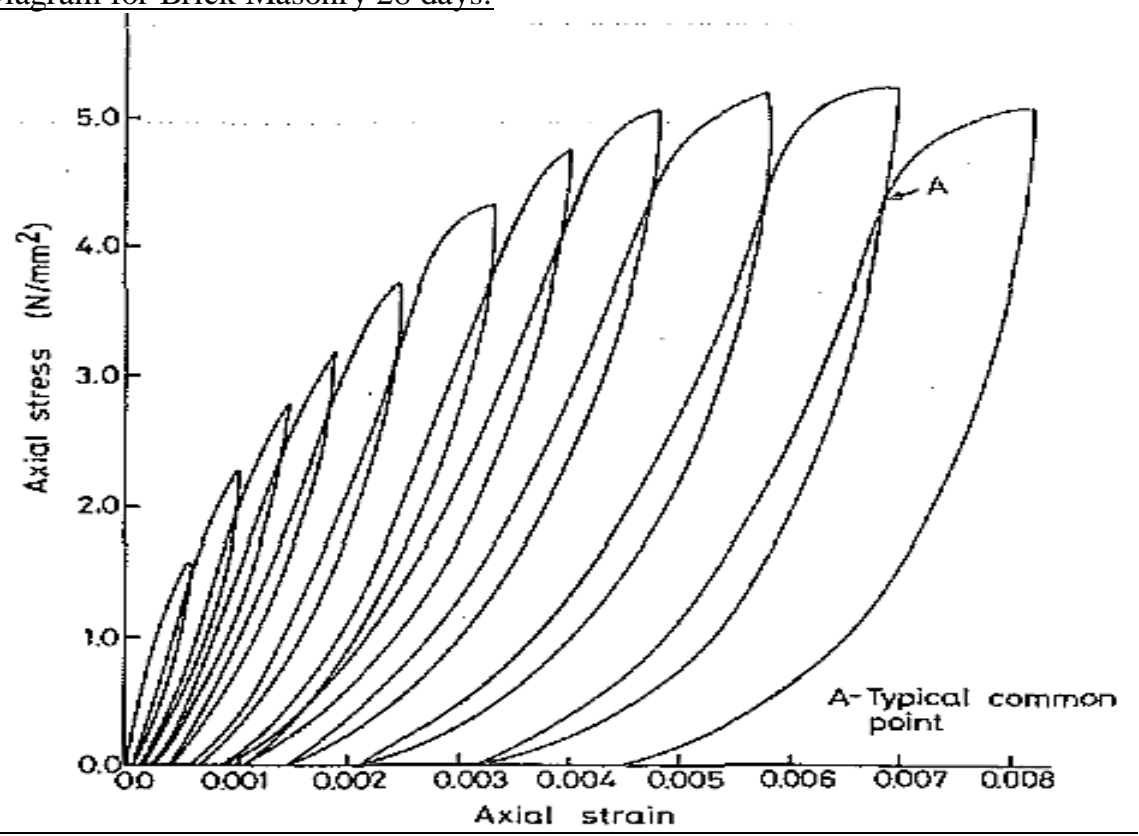

Figure 11: Stress-Strain Diagram for 28 days of Brick masonry prism

4. Sress-Strain Diagram for Concrete Masonry 28 days (Kaushik et al, 2008):

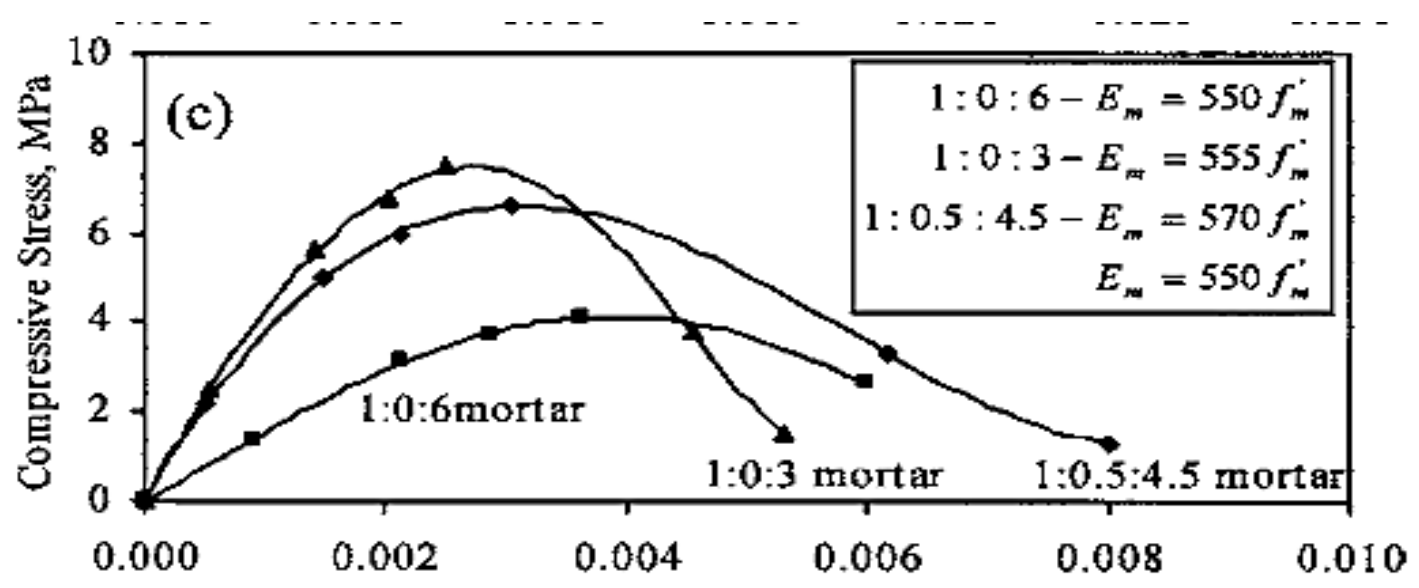

Figure 12: Stress-Strain Diagram for 28 days of Concrete masonry prism 


\section{CONCLUSION \& FUTURE SCOPE}

This Study was about the compressive strength analysis and cracking patterns of Interlocking pattern of concrete blocks. In this study two different types of blocks were studied. These are studied for change in compressive strength with respect to brick masonry and simple concrete masonry.It is seen that the compressive strength of this type of masonry is higher than that of both brick and concrete masonry when interlocking mortar is considered. However, it is comparable with highest grade concrete blocks of Kaushik et al in strength when the effect of the interlocking mortar is not considered.

The increase in strength w.r.t. the concrete masonry hollow is by $20 \%$ and w.r.t. the brick is by $40 \%$. Besides, the increase in compressive strength is also witnessed when compared with the interlocking features. Interlocking mortar increases strength by $30 \%$ w.r.t. the prism without interlocking mortar.

Further cost saving is achieved because the simplicity with which the blocks can be laid and aligned reduces the number of high wage skilled masons required on a construction project. When compared to convention masonry block construction, interlocking blocks, which are dry assembled, save a great deal of mortar Because of the ease and economy with which interlocking block walls can be built, load bearing walls can be used where infill walls would normally be placed, thereby providing both additional strength and load bearing ability to accept future additions to the building. Interlocking block construction techniques can be used for everything from single to multi-story construction

Future scope of this is to study:

1. Different types of interlocking patterns

2. Compressive strength and flexural strength features

3. Hollow and interlocks combined

4. Grooves and tenon features

5. Hollow patterns and their interlocks

\section{ACKNOWLEDGEMENTS}

The authors are thankful to Dr. J. A. Naqash, Associate Professor, Department of Civil Engineering, National Institute of Technology, Srinagar, J\&K, India and Er. Shujat Hussain, Assistant Professor, Department of Civil Engineering, Islamic University of Science and Technology, Awantipora, J\&K, India and Dr. Shakeel Ahmad Engineering Geologist JKSPDC Srinagar J\&K India.

\section{REFERENCES}

[1] Design of masonry structures-Part 1-1: Common rules for reinforced and unreinforced masonry structures", EN 1996, 131p.

[2] http://www.testmark.net/showitem-487.html.

[3] Types of Stone Construction Masonry | eHow http://www.ehow.com/info.

[4] Status Report, U.S. Coordinated Program for Masonry Building Research," Technical Coordinating Committee for Masonry Research, Nov. 1988.

[5] H.G. Harris. K. Oh, and A. A. Hamid Development of New interlocking and Mortar less Block Masonry Units for Efficient Building Systems." Volume 2, pp. 72 3-734.Proceedings of the 6th Canadian Masonry Symposium, Saskatoon. Saskatchewan, Canada, 1992.

[6] P. J. Mancini \& Associates. Structural Engineers, 'Design Methodology-The Haener Interlocking Mortarless Block System" August 1989.

[7] Smith, David R. Permeable Interlocking Concrete Pavements: Design, Specifications, Construction, Maintenance, 4th Edition, Interlocking Concrete Pavement Institute, Washington, DC, 2011.

[8] ANSI A118.8-99, Modified Epoxy Emulsion Mortar/Grout. New York: American National Standards Institute, 1999.

[9] ANSI A136.1-99, Organic Adhesives for Installation of Ceramic Tile. New York: American National Standards Institute, 1999.

[10] ANSI A137.1-88, Ceramic Tile. New York: American National Standards Institute, 1988.

[11] ASCE 7-02, Minimum Design Loads for Buildings and Other Structures. Reston, VA: American Society of CivilEngineers, 2002.

[12] Borchelt, J. G., Danforth, L.. Jr., and Hunsicker, R., "Specifying Brick: Getting what you want for appearance and function," The Construction Specifier, Construction Specifications Institute, Alexandria, VA, January 2006, pp.20-28.

[13] CSA A82, Fired Masonry Brick Made from Clay or Shale, Canadian Standards Association, Mississauga,Ontario, Canada, 2006. 
[14] Annual Book of ASTM Standards, ASTM International, West Conshohocken, PA 2006: Volume 04.02 Concrete and Aggregate ASTM C 88 Test Method for Soundness of Aggregates by Use of Sodium Sulfate ASTM C 418 Test Method for Abrasion Resistance of Concrete by Sandblasting.

[15] Environmental and Social Review for Fal-G bricks projects, Eco Carbon Private Limited, Jan 2006, pp.614.

[16] M.S.Shetty, Concrete Technology, S. Chand and Company Ltd, New Delhi.

[17] M.L. Gambhir, Concrete Manual, Dhanpat Rai and Sons, New Delhi.

[18] Bansal Deepak, CBRI ROORKEE, India, Feb 2009.

[19] Dawar Deepak, Hydraform India Pvt Ltd; www.hydraformasia.com.

[20] Gujarat State Disaster Management Authority, India, Guidelines.

[21] Cercorp Initiatives Inc. (2010). "FlexLock wall system \{online\}". Available from http:// www.cercorp.com/ [cited 03/29 2010].

[22] "Development and Performance Evaluation of Interlocking Block-Masonry" K.B. Anand and Ramumarthy, Journal of Architectural Engineering, 2000. 